\title{
Chicken egg yolk antibodies (IgY) as non-antibiotic production enhancers for use in swine production: a review
}

Xiaoyu Li ${ }^{1,2}$, Lili Wang ${ }^{1,2}$, Yuhong Zhen ${ }^{3}$, Shuying $\mathrm{Li}^{4}$ and Yongping $\mathrm{Xu} \mathrm{u}^{1,2^{*}}$

\begin{abstract}
In recent years, the use of in-feed antibiotics for growth and disease prevention in livestock production has been under severe scrutiny. The use and misuse of in-feed antibiotics has led to problems with drug residues in animal products and increased bacterial resistance. Chicken egg yolk antibodies (IgY) have attracted considerable attention as an alternative to antibiotics to maintain swine health and performance. Oral administration of IgY possesses many advantages over mammalian IgG such as cost-effectiveness, convenience and high yield. This review presents an overview of the potential to use lgY immunotherapy for the prevention and treatment of swine diarrhea diseases and speculates on the future of IgY technology. Included are a review of the potential applications of IgY in the control of enteric infections of either bacterial or viral origin such as enterotoxigenic Escherichia coli, Salmonella spp., rotavirus, porcine transmissible gastroenteritis virus, and porcine epidemic diarrhea virus. Some potential obstacles to the adoption of IgY technology are also discussed.
\end{abstract}

Keywords: Diarrhea, Disease control, Egg yolk antibodies, IgY, Swine

\section{Introduction}

Antibiotics have been widely used in the swine industry for more than 50 years. The efficacy of antibiotics in increasing growth rate, improving feed utilization, and reducing incidence of disease is well documented [1]. In general, sub-therapeutic levels of antibiotics in swine diets increase the growth rate by an average of $16 \%$ in weanling pigs, $11 \%$ in growing pigs, and $4 \%$ in growing-finishing pigs [1]. In addition, antibiotics are also used for disease prevention (prophylactic doses) and treatment (therapeutic doses). However, serious concerns have arisen with regard to the potential risks for human health including drug residues in meat products and increased bacterial resistance due to the use and misuse of in-feed antibiotics [2]. As a result, the European Union has totally banned the use of antibiotics for growth promotion since January 2006 [3], while the US Food and Administration (FDA) has been

\footnotetext{
* Correspondence: xiaoyuli@dlut.edu.cn

'School of Life Science and Technology, Dalian University of Technology,

Dalian 116024, China

${ }^{2}$ Ministry of Education Center for Food Safety of Animal Origin, Dalian

116620, China

Full list of author information is available at the end of the article
}

phasing out non-medical antibiotic use for livestock since December 2013 [4].

Diarrheal disease is a frequent cause of heavy economic losses for swine producers. A major challenge currently facing the swine industry is to develop alternative means for controlling diarrhea in young pigs (particularly neonatal and early-weaned piglets) that are not only cost effective, but also allow for sustainable pork production. In the past two decades, a variety of materials have been tested as effective alternatives to antibiotics to maintain swine health and performance. The most widely researched alternatives include enzymes [5], organic acids [6], pro- and prebiotics [7-9], herbal extracts $[10,11]$ and neutraceuticals such as copper and zinc $[12,13]$. However, these alternatives produce limited growth promotion and protection against pathogens.

Recently, egg yolk antibodies, generally referred to as IgY, have attracted considerable interest as an alternative to antibiotics for growth promotion in the presence of disease causing organisms [14]. IgY possesses a large number of advantages over mammalian IgG such as cost-effectiveness, convenience, and high yield [15]. Oral 
administration of specific IgY antibodies has been shown to be highly effective against a variety of intestinal pathogens which cause diarrhea in animals and human such as enterotoxigenic Escherichia coli (ETEC), Salmonella spp., bovine and human rotaviruses, bovine coronavirus, porcine transmissible gastroenteritis virus (TGEV), and porcine epidemic diarrhea virus (PEDV) [14, 16].

Following a brief description of IgY technology and the advantages of IgY, this review will focus on the potential to use specific IgY as a production enhancer in swine production, and discuss the potential obstacles to the adoption of IgY technology.

\section{IgY technology}

As described more than 100 years ago, Klemperer [17] first demonstrated that avian maternal antibodies are transferred from serum to egg yolk in order to protect the developing embryo from potential pathogens but at that time there was no scientific application for this knowledge. However, when animal welfare became a matter of serious ethical concern for the scientific community, the results of Klemperer began to receive more interest, particularly since the 1980s.

Since 1996, IgY technology (i.e. the production and use of IgY) has become an internationally accepted practice [18]. In 1996, the European Centre for the Validation of Alternative Methods (ECVAM) workshop strongly recommended that IgY should be used as an alternative to mammalian antibodies [19]. In 1999, IgY technology was approved as an alternative method for supporting animal welfare by the Veterinary Office of the Swiss Government (Office Vétérinaire Fédéral).

Details concerning the production of specific IgY have been reviewed by Schade et al. (2005) [20]. Briefly, in order to produce specific IgY antibodies, laying hens are immunized with specific foreign pathogens which induce immune responses, including the production of antibodies with activity against these specific disease conditions. These antibodies are then transferred to the egg yolk and deposited in large quantities. Booster immunizations are usually given to ensure continued transfer of antibodies from the hen's serum to the egg yolk. These antibodies are then extracted from the egg yolk and processed to be administered directly to the animal or incorporated into diets.

Antibodies can be administered in several forms including whole egg powder, whole yolk powder, a water-soluble fraction powder or purified IgY. Antibody production and titer development as a result of immunization are not very predictable. Variables influencing immunization include the antigen (dose, MW), type of adjuvant used, route of immunization, immunization frequency and the chicken itself (such as housing conditions, age, breed, egg laying capacity).

\section{Advantages of $\lg Y$}

The use of chickens as the immunization host for antibody production provide a number of advantages over production methods using mammals. The most significant advantage is that egg collection is non-invasive compared with the stressful bleeding of animals to obtain serum. In addition, the high and long-lasting titer produced in chickens reduces the need for frequent booster injections. Another advantage is that the production of IgY antibodies against highly conserved mammalian proteins is more successful in chickens than in other mammals [21] and requires much less antigen to induce an efficient immune response due to the phylogenetic distance between chickens and mammals [22].

A hen can be considered as a small "factory" for antibody production. One hen can produce more than $22.5 \mathrm{~g}$ of total IgY per year of which 2 to $10 \%$ are specific antibodies [14]. This extraordinary quantity is equivalent to the production of 4.3 rabbits over the course of a year. The cost for maintaining laying hens are also lower than those for mammals such as rabbits [20]. Therefore, egg yolk offers a more hygienic, costefficient, convenient and rich source of antibodies compared with traditional production methods using mammals. In contrast to antibiotics, the use of IgY is environmentally-friendly and elicits no undesirable side effects, disease resistance or toxic residues [23].

In terms of function, unlike mammalian IgG, IgY does not activate mammalian complement and also does not interact with mammalian Fc and complement receptors. As well, IgY does not bind to protein A, protein G or rheumatoid factor [15]. These differences provide great advantages for the successful application of IgY technology in many research areas, diagnostics [24], antibioticalternative therapy [15] and xenotransplantation [25].

\section{Mode of action}

The exact mechanisms through which IgY counteracts pathogen activity have not been determined. However, several mechanisms have been proposed by $\mathrm{Xu}$ et al. (2011) [14] including agglutination of bacteria, inhibition of adhesion, as well as opsonization followed by phagocytosis and toxin neutralization. Among these, inhibition of adhesion is considered the primary mechanism by which specific IgY functions. Briefly, IgY antibodies generated against intestinal disease causing organisms may reduce the incidence of disease by preventing the attachment of pathogens to the intestine, such as blocking the mucosal receptor, interfering with binding to mucins, or neutralizing the colonization factor (such as the outer membrane protein, lipopolysaccharide, fimbriae (or pili), 


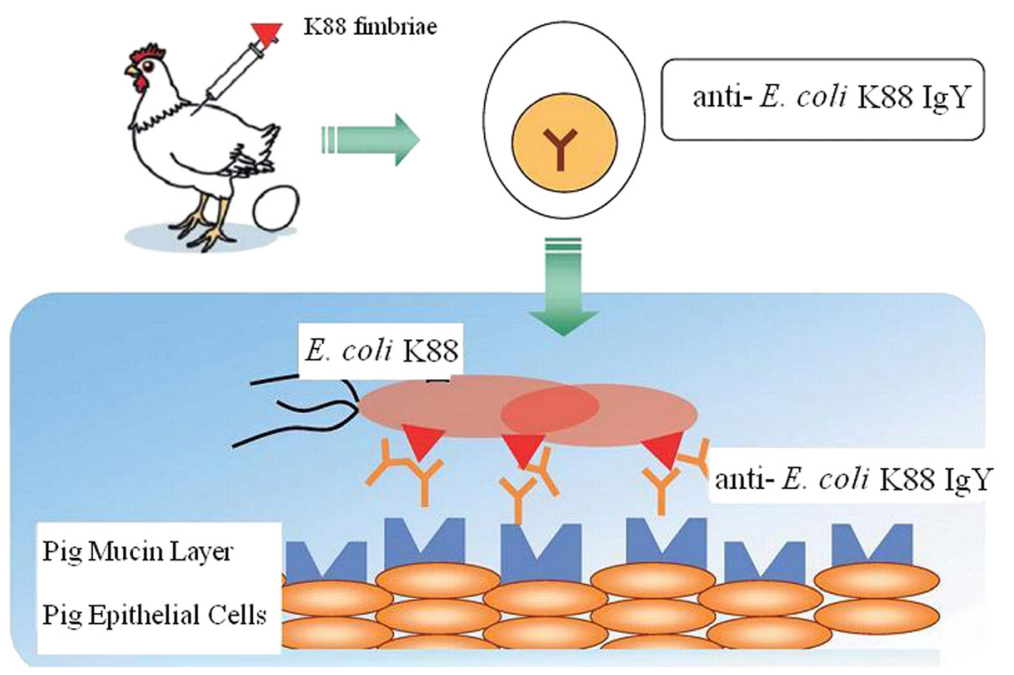

Fig. 1 Possible primary mode of action by which IgY protects pigs against E coli K88 induced diarrhea. Modified from Hatta et al. [85]

and flagella) [26]. The possible primary mode of action by which IgY protects pigs against $E$ coli $\mathrm{K} 88$ induced diarrhea is illustrated in Fig. 1.

\section{IgY applications in swine production}

Diarrhoea in neonatal and post-weaning pigs can be caused by a number of causative agents and has become a serious problem in the swine industry due to the trend towards large intensive herds and early weaning (i.e. 14-21 rather than $21-28$ days of age). The potential applications for using orally administered IgY in the control of enteric infections of either bacterial or viral origin in piglets have been studied at length and are summarized in Tables 1 and 2 .

\section{Antimicrobial and performance effects Enterotoxigenic Escherichia coli}

Diarrhea due to enterotoxigenic Escherichia coli (ETEC) is by far the most common enteric colibacillosis encountered in neonatal and post-weaned pigs [27-29]. ETEC can cause diarrhea in piglets by colonization in the small intestine and thereafter through the production of either one or two enterotoxins namely heat-labile enterotoxin (LT) and heat-stable enterotoxins (ST), which induce massive fluid and electrolyte secretion into the gut lumen [30].

The strains of $E$. coli associated with intestinal colonization which cause severe diarrhea are those expressing the K88 (or F4), K99 (or F5), 987P (or F6), F18 and F41 fimbrial adhesions. These fimbrial adhesions mediate the adhesion of $E$. coli to the epithelial mucosa lining of the intestine and thereby contribute to their virulence. Among the different ETEC, those expressing the K88+ fimbrial antigen are the most prevalent forms causing E. coli infection world-wide [31]. It has been estimated that K88 + ETEC are responsible for more than half of the piglet mortality which occurs annually [32].

Oral administration of IgY offers a potential prophylactic and therapeutic approach for controlling E. coli-induced diarrhea in piglets. IgY has been shown to successfully control intestinal infections of E. coli K88, K99, 987P, and F18 in young pigs [27, 33, 34]. Yokoyama et al. [27] showed that orally administered crude IgY (the water-soluble fraction) generated against E. coli K88, K99, or 987P fimbriaes was protective against infection from three homologous strains of $E$. coli in a dosedependent manner in colostrum-deprived piglets. In vitro, E. coli $\mathrm{K} 88$, K99, and 987P strains adhered equally to porcine epithelial cells from the duodenum and ileum but failed to so in the presence of homologous antifimbrial IgY [27].

The group of Marquardt [26, 34] from the University of Manitoba in Canada carried out some excellent studies on the passive protective effects of IgY against ETEC K88 fimbriae in neonatal and early-weaned piglets. In an animal feeding study, 21-day old pigs were orally challenged with high doses of ETEC K88 at 0 and $5 \mathrm{~h}$ of the experiment. They were then oral administered with crude IgY (the water-soluble fraction) three times a day for two consecutive days after the first $E$. coli challenge. Control piglets (treated with IgY from non-immunized hens) had severe diarrhea within $12 \mathrm{~h}$ and lost weight and $30 \%$ of the pigs died within $48 \mathrm{~h}$ of infection. In contrast, the pigs given IgY from immunized hens exhibited no signs of diarrhea 24 and $48 \mathrm{~h}$ after treatment, and had a positive weight gain. Furthermore, this group performed studies on the practical use of IgY in a field trial. Their experiment showed suppression of the incidence and severity of diarrhea in 14-18-day-old weaned 
Table 1 Effect of IgY against diarrhea caused by bacterial pathogens in piglets

\begin{tabular}{|c|c|c|c|c|c|}
\hline \multirow[t]{2}{*}{ Items } & & & \multicolumn{2}{|l|}{ Mortality, \% } & \multirow{2}{*}{$\begin{array}{l}\text { Outcome measure } \\
\text { considered-Mortality } \\
\text { (M) or Diarrhea (D) }\end{array}$} \\
\hline & & & Intervention & Control & \\
\hline \multicolumn{6}{|l|}{ Prophylactic effect } \\
\hline Ref. & Pathogens & Piglet age & & & \\
\hline \multirow[t]{3}{*}{ Imberechts et al. [33] } & F18+ ETEC & Weaned (21-28 d) & 33 & 66 & $\mathrm{D}$ \\
\hline & F18+ ETEC & Weaned (21-28 d) & 25 & 75 & $\mathrm{D}$ \\
\hline & F18+ ETEC & Weaned (21-28 d) & 0 & 25 & M \\
\hline \multirow[t]{3}{*}{ Marquardt et al. [34] } & K88+ ETEC & Neonatal (3-day-old) & 12.5 & 62.5 & M \\
\hline & K88+ ETEC & Weaned (21-day-old) & 0 & 30 & M \\
\hline & K88+ ETEC & Weaning (14-18-days-old) & 1.9 & 3.9 & $\mathrm{D}$ \\
\hline \multirow[t]{2}{*}{ Owsu-Asiedu et al. [36] } & K88+,F18+, F41+ ETEC & Early-weaned (10-day-old) & 30 & 73 & $\mathrm{D}$ \\
\hline & ETEC K88+, F18, F41 & Early-weaned (10-day-old) & 33 & 100 & $\mathrm{D}$ \\
\hline Owsu-Asiedu et al. [37] & $\mathrm{K} 88+\mathrm{ETEC}$ & Early-weaned $(10 \pm 1$ days old $)$ & 6.6 & 40 & M \\
\hline Owsu-Asiedu et al. [38] & $\mathrm{K} 88+\mathrm{ETEC}$ & Early-weaned (10-day-old) & 0 & 33 & M \\
\hline Chernysheva et al. [76] & $\mathrm{K} 88+\mathrm{ETEC}$ & Newly weaned (about 22-day-old) & 66 & 58.3 & $\mathrm{D}$ \\
\hline Chu et al. [86] & $\mathrm{K} 88+\mathrm{ETEC}$ & Neonatal (3-day-old) & 16.7 & 66.7 & M \\
\hline Li et al. [83] & $\mathrm{K} 88+\mathrm{ETEC}$ & Weaned (40-day-old) & 0 & 75 & $\mathrm{D}$ \\
\hline \multicolumn{6}{|l|}{ Therapeutic effect } \\
\hline Ref. & Pathogens & Piglet age & & & \\
\hline \multirow[t]{3}{*}{ Yokoyama et al. [27] } & $\mathrm{K} 88+\mathrm{ETEC}$ & Newborn & 0 & 86 & M \\
\hline & $\mathrm{K} 99+\mathrm{ETEC}$ & Newborn & 0 & 100 & M \\
\hline & $987 P+E T E C$ & Newborn & 0 & 80 & M \\
\hline Yokoyama et al. [87] & F18+ ETEC & Weaned (28-day-old) & 0 & 11 & $\mathrm{D}$ \\
\hline \multirow[t]{3}{*}{ Yang et al. [88] } & $\mathrm{K} 88+\mathrm{ETEC}$ & Newborn & 0 & 85.7 & M \\
\hline & $\mathrm{K} 99+\mathrm{ETEC}$ & Newborn & 0 & 100 & M \\
\hline & $987 P+E T E C$ & Newborn & 0 & 80 & M \\
\hline \multirow[t]{3}{*}{ Xu et al. [89] } & $\mathrm{K} 88+\mathrm{ETEC}$ & Newborn & 0 & 33.3 & M \\
\hline & $\mathrm{K} 99+\mathrm{ETEC}$ & Newborn & 0 & 66.7 & M \\
\hline & $987 P+$ ETEC & Newborn & 0 & 50 & M \\
\hline Chu et al. [86] & K88 + ETEC & Weaned (21-day-old) & 0 & 25 & M \\
\hline
\end{tabular}

piglets fed specific IgY powder, which were much lower than those fed a commercial diet containing an antibiotic. The number of pigs in this study was not large and it would be desirable to repeat this study with a greater number of animals.

In another study with $\mathrm{F} 18+E$. coli, it was shown that the F18 antibodies diminished the incidence of diarrhea and death in weaned piglets infected with $\mathrm{F} 18+E$. coli [33]. Zuniga et al. [35] also reported that weaned pigs fed a basal feed plus $5 \%(\mathrm{w} / \mathrm{w})$ egg powder with IgY antibodies against the same fimbrial variant (F18ab or F18ac) were fully protected when the pigs were challenged with $\mathrm{F} 18+$ E. coli.

In addition to reducing the incidence and severity of piglet diarrhea, several studies have shown that IgY has growth promoting effects in early-weaned pigs, similar to spray-dried animal plasma and spray-dried porcine plasma [36-39]. Table 3 shows the results of an experiment where the performance of pigs fed specific anti-K88 antibodies was compared with that of pigs fed diets supplemented with zinc oxide, fumaric acid or antibiotics after oral ETEC K88 challenge [37]. All four feed additives successfully increased pig performance compared with unsupplemented pigs with significant reductions observed in scour score and piglet mortality. In this experiment, IgY was equal to antibiotics in enhancing pig performance. Table 4 shows the effects of adding egg yolk containing specific anti-K88 antibodies (EGG), EGG-exchange, or spray dried porcine plasma to a corn-soybean meal-based $(\mathrm{CON})$ diet on performance, plasma urea and weight of pancreas of weaned pigs that were not challenged with ETEC K88 challenge [39]. The results show that addition 
Table 2 Effect of IgY against diarrhea caused by viral pathogens in piglets

\begin{tabular}{|c|c|c|c|c|c|}
\hline \multirow[t]{2}{*}{ Items } & & & \multicolumn{2}{|l|}{ Mortality, \% } & \multirow{2}{*}{$\begin{array}{l}\text { Outcome measure } \\
\text { considered-Mortalit) } \\
\text { (M) or Diarrhea (D) }\end{array}$} \\
\hline & & & Intervention & Control & \\
\hline \multicolumn{6}{|l|}{ Prophylactic effect } \\
\hline Ref. & Pathogens & Piglet age & & & \\
\hline \multirow[t]{3}{*}{ Kweon et al. [66] } & PEDV & Neonatal (3-day-old) & 26 & 58 & M \\
\hline & PEDV & Neonatal (3-day-old) & 41 & 71 & M \\
\hline & PEDV & Neonatal (3-day-old) & 50 & 66 & M \\
\hline Zuo et al. [61] & TGEV & Newborn & 12.5 & 57 & M \\
\hline Vega et al. [73] & Human Rotavirus & Neonatal (1-day-old) & 0 & 100 & $\mathrm{D}$ \\
\hline \multicolumn{6}{|l|}{ Therapeutic effect } \\
\hline Ref. & Pathogens & Piglet age & & & \\
\hline Song et al. [67] & PEDV & Neonatal (1-day-old) & 16.7 & 100 & M \\
\hline Cui et al. [62] & TGEV, PEDV & Neonatal (1-day-old) & 0 & 100 & M \\
\hline
\end{tabular}

of EGG to the CON diets reduced plasma urea nitrogen concentration, and increased feed intake by $23 \%$ and tended to increase weight gain by $28 \%$ in phase II. This study indicates that inclusion of EGG in the diets for pigs immediately after weaning can significantly affect their future growth performance. Unfortunately, limited numbers of pigs were used in this study and a repeat with greater numbers would certainly be welcomed.

Although adhesin-mediated colonization is a precondition for ETEC pathogenesis, enterotoxins are thought to be the central virulence determinants leading to diarrhea diseases and may also play a role in the colonization process $[30,40,41]$. Therefore, the ideal protective agent against ETEC infection should include protection against both adhesin antigens and enterotoxins [30]. In contrast with LTB and STa, enterotoxins STa and STb are poorly immunogenic because of their small size, but they can attain immunogenicity when coupled chemically or genetically to an appropriate carrier [42, 43]. In order to make useful toxoids, we constructed polyvalent enterotoxin STa-LTB-STb DNA and protein vaccines endowing immunogenicity to both STa and STb [44]. Laying hens were immunized with DNA vaccines and obtained antitoxic antibodies from egg yolks and this was confirmed by indirect ELISA. The polyvalent DNA vaccine pCISTa-LTB-STb expressed the STa-LTB-STb fusion peptide in vitro in cultured Hela cells. These egg yolk antibodies were able to neutralize the natural toxicity of STa and LTb with the highest dilution of $1 / 2$ and $1 / 32$ in a suckling mouse assay [45]. These results indicate that the recombinant STa-LTB-STb protein has the potential to serve as an effective and convenient polyvalent toxoid which can provide broad protection against ETECinduced diarrhea. This study was conducted with mice and a piglet study should be conducted to confirm these findings.

\section{Salmonella}

Salmonella infection has been recognized as one of the most common foodborne diseases in humans, causing 1.4 million cases with an estimated economic impact of $\$ 2.4$ billion each year in the United States [46, 47]. This disease can occur via foodborne transmission, animal contact, or environmental spread [48, 49], and farm

Table 3 Effect of IgY, zinc oxide, fumaric acid and antibiotics on the performance and intestinal morphology of 10 to 24 day old pigs fed diets based on pea protein concentrate

\begin{tabular}{|c|c|c|c|c|c|c|}
\hline Items & Control & $\lg Y$ & Zinc oxide & Fumaric acid & Carbadox & SEM \\
\hline Weight gain, g/d & 100.9 & 151.2 & 158.9 & 155.4 & 152.6 & 16.6 \\
\hline Feed intake, $\mathrm{g} / \mathrm{d}$ & 141.0 & 208.1 & 214.7 & 211.6 & 222.4 & 15.3 \\
\hline Feed conversion & 1.39 & 1.38 & 1.35 & 1.36 & 1.45 & 0.04 \\
\hline Scour score & 2.7 & 1.3 & 1.4 & 1.3 & 1.1 & - \\
\hline Mortality, \% & 40.0 & 6.6 & 13.3 & 6.6 & 13.3 & - \\
\hline Villus height, m & 355 & 564 & 488 & 573 & 570 & 20.0 \\
\hline Crypt depth, m & 204 & 183 & 190 & 207 & 204 & 10.1 \\
\hline Villous height/crypt depth & 1.7 & 3.1 & 2.6 & 2.8 & 2.8 & 0.11 \\
\hline
\end{tabular}


Table 4 Effect of EGG, EGG-X, or SDPP on performance, plasma urea and pancreas weight of weaned pigs fed diets based on corn-soybean meal ${ }^{1}$

\begin{tabular}{|c|c|c|c|c|c|}
\hline Items & Control & EGG & EGG-X & SDPP & SEM \\
\hline \multicolumn{6}{|l|}{ Weight gain, g/d } \\
\hline d 0-14 & $124^{\mathrm{b}}$ & $151^{\mathrm{ab}}$ & $128^{b}$ & $185^{\mathrm{a}}$ & 12.4 \\
\hline d $14-25$ & 332 & 425 & 349 & 398 & 25.9 \\
\hline \multicolumn{6}{|l|}{ Feed intake, g/d } \\
\hline d 0-14 & 191 & 219 & 197 & 222 & 12.3 \\
\hline d $14-25$ & $530^{\mathrm{b}}$ & $655^{\mathrm{a}}$ & $583^{\mathrm{ab}}$ & $610^{\mathrm{ab}}$ & 37.4 \\
\hline \multicolumn{6}{|l|}{ Feed conversion } \\
\hline d 0-14 & 1.43 & 1.43 & 1.47 & 1.18 & 0.067 \\
\hline d $14-25$ & 1.54 & 1.54 & 1.67 & 1.54 & 0.033 \\
\hline \multicolumn{6}{|l|}{ Plasma urea $\mathrm{N}, \mathrm{mmol} / \mathrm{L}$} \\
\hline d 0-14 & 3.8 & 3.9 & 4.3 & 3.7 & 0.34 \\
\hline d 14-25 & $3.4^{\mathrm{a}}$ & $3.0^{\mathrm{b}}$ & $3.6^{a}$ & $2.6^{b}$ & 0.22 \\
\hline Pancreas, $\mathrm{g} / \mathrm{kg}$ of body weight & $1.07^{\mathrm{b}}$ & $1.22^{\mathrm{ab}}$ & $1.34^{\mathrm{a}}$ & $1.08^{\mathrm{b}}$ & 0.071 \\
\hline
\end{tabular}

animals are the most likely source of human salmonellosis $[50,51]$. Therefore, it is important to control this disease, not only to reduce productive losses in domestic livestock, but also to prevent its transmission into the human food chain. Salmonella species, S. enteritidis and S. typhimurium, in particular, are thought to be the major agents of human salmonellosis [46]. They are non-host serotypes which can cause disease syndromes like gastroenteritis and systemic infectious in a wide range of animal species, including humans.

Studies by Yokoyama et al. [52] investigated the efficacy of IgY antibodies specific for outer membrane protein (OMP), lipopolysaccharide (LPS), or flagella (Fla) for controlling S. typhimurium or S. enteritidis. They treated mice orally with an appropriate placebo or purified IgY following a challenge with S. enteritidis. Antibody treatment resulted in survival rates of 80,47 and $60 \%$ using OMP-, LPS-, and Fla-specific antibodies, in contrast to survival rates of only $20 \%$ in control mice. In the S. typhimurium trial, the survival rate was 40,30 and $20 \%$ using OMP-, LPS-, or Fla-specific antibodies, in contrast to $0 \%$ in the control mice. These preliminary results suggest that antibodies against specific Salmonella proteins can control salmonellosis when orally administrated to mice.

Studies with pigs have been reported [53, 54]. Unfortunately, reports where similar benefits of IgY to those found in mice were not obtained with pigs. Mathew et al. [53] found that feeding egg yolk powder containing anti-Salmonella IgY antibodies may not be particularly effective in reducing Salmonella shedding in pigs. In this experiment, specific egg yolk powder derived from chickens challenged with purified Salmonella typhimurium antigens (fimbrial protein, OMP, and LPS) was included in swine feed. Treatments were provided beginning on day 3 of the experiment, and all pigs were challenged with Salmonella typhimurium on day 7 . Fecal samples were collected on days $0,7,8,12$, $14,21,58,88$, and 118 to determine shedding of Salmonella. The results showed that in-feed IgY antibodies did not diminish the shedding of Salmonella, and was inferior to antibiotic treatment. The failure of IgY to improve performance is suspected to be due to the fact that the invasive nature of Salmonella allowed the organism to by-pass the gut and the dietary treatments by moving through vascular and/or lymphatic routes directly into the colon [55-57]. However, available data are still too limited to allow reliable conclusions regarding the possible efficacy of IgY to control Salmonella infection in swine.

\section{Antiviral and performance effects \\ Porcine transmissible gastroenteritis virus}

Porcine transmissible gastroenteritis virus (TGEV), a porcine coronavirus, can cause a highly contagious enteric infection in swine of all ages [58]. The infected piglets develop significant clinical signs, including vomiting, emaciation and severe diarrhea. The disease is especially severe in the animals less than 2 weeks old with a mortality of nearly $100 \%[59,60]$. With the lack of successful vaccines to prevent a TGE outbreak, the disease occurs frequently in swine farms. It has been shown that specific IgY has great potential as an alternative prophylactic approach like colostral antibodies against TGEV $[61,62]$. In a prophylactic efficacy experiment, oral administration with IgY significantly increased newborn piglet survival rate $(87.5 \%)$ after challenge exposure compared with the control (43\%), whereas the therapeutic effects demonstrate that mortality was dramatically reduced by orally administered IgY in two farms that showed TGEV positive results [61]. Unfortunately, piglet performance was not monitored in this study.

\section{Porcine epidemic diarrhea virus}

Porcine epidemic diarrhea virus (PEDV) is another important enteric viral pathogen that is responsible for neonatal piglet diarrhea $[63,64]$. Although the clinical symptoms of PEDV infection are similar to TGEV infection, PEDV is antigenically different from TGEV. Epidemiological observations have indicated that the spread of disease seems to be slower, but rather persistent compared with a TGEV outbreak [65]. It has been shown that IgY can be an alternative method for conferring protection in piglets against PEDV [62, 66, 67]. IgY 
was found to reduce mortality in piglets after challenge exposures. The field application of IgY from three farms also revealed the survival rate was increased significantly in pigs treated with $\operatorname{IgY}(49.24 \%)$ compared with a control group $(33.71 \%)$.

\section{Rotavirus}

Rotavirus is a major pathogen of infectious gastroenteritis, not only in children and infants, but also in domestic animals. In humans alone, it has been estimated that rotavirus infections result in several million deaths each year [68]. Animals are also seriously affected by this virus. Rotavirus from calves, pigs, mice, foals, infant humans, lambs, chickens, and turkey are antigenically related [69]. Therefore, the appropriate anti-rotavirus antibodies will react with the virus present in any of these species.

IgY has been shown to successfully control intestinal infection of rotavirus in newborn calves and mice [70-73]. Studies with pigs have been reported and similar positive results were obtained [74]. A passive treatment based on human rotavirus specific IgY antibodies not only prevented gnotobiotic piglets from developing diarrhea caused by the prevalent strain of Wa G1P [8] HRV, but also significantly reduced the amount of infectious virus shed compared with a negative control group.

\section{Current challenges}

There are many obstacles that can limit the use of IgY for the control of diarrhea diseases in swine. The most important issues which need to be addressed are as follows.

The stability of $\lg Y$ in the gastrointestinal tract when they are fed to swine

Although the beneficial effects of pathogen-specific IgY in animals have been known for about 20 years, results on the experimental application of these antibodies in swine have not always been consistent. There are several reports where IgY failed to improve pig performance $[75,76]$. The most likely explanation for the failure of the treatment is that the antibody failed to survive passage through the gastrointestinal tract as a result of its susceptibility to proteolysis [77]. IgY, being a glycoprotein, is sensitive to the same denaturing conditions as most proteins. It has been reported that IgY is fairly resistant to digestion by intestinal proteases, but the activity of IgY was decreased at $\mathrm{pH} 3.5$ or lower and almost completely lost with irreversible change at $\mathrm{pH} 3$ [78]. In addition, the inactivation at low $\mathrm{pH}$ is further enhanced by the presence of pepsin. In contrast to very young pigs, the stomach of older pigs has a low $\mathrm{pH}$ and pepsin, and therefore IgY may not be effective in controlling post-weaning E. coli diarrhea in older animals.

Yokoyama et al. [79], in an excellent study, detected the rate of IgY passage through the gastrointestinal tract of pigs and its ability to retain its activity in the different sections of the tract. Their results demonstrated that IgY is readily absorbed within $24 \mathrm{~h}$ by the newly born pig. IgY has a serum half-life of 1.85 days in newborn pigs, which is shorter than the reported serum half-life of 12 to 14 days for homologous IgG (colostral antibodies). The amount of IgY absorbed into the circulation when administered in pigs decreased with increasing age of pigs.

Since the primary target site of $\operatorname{IgY}$ is the small intestine, in order for it to function, it must be able to survive passage through the harsh environmental conditions found in the stomach. Microencapsulation techniques have been developed to protect IgY from gastric inactivation [77, 80-83]. Table 5 shows the results of an experiment where chitosan-alginate microcapsules were used for oral delivery of egg yolk immunoglobulin in weaned pigs challenged with enterotoxigenic $E$. coli K88 [83]. The percentage of pigs with diarrhea $24 \mathrm{~h}$ after treatment and the diarrhea score were improved in pigs receiving encapsulated IgY compared with non-

Table 5 Effect of encapsulated IgY on performance and the incidence of diarrhea in pigs challenged with K88+ ETEC

\begin{tabular}{|c|c|c|c|c|c|c|c|}
\hline \multirow[t]{2}{*}{ Items } & \multirow{2}{*}{$\begin{array}{l}\text { No. of } \\
\text { pigs }\end{array}$} & \multicolumn{4}{|c|}{ Percentage of pigs with diarrhea after specific times (Fecal score in brackets ${ }^{2}$ ) } & \multirow{2}{*}{$\begin{array}{l}\text { Weight gain, } \\
\mathrm{g}^{3}\end{array}$} & \multirow{2}{*}{$\begin{array}{l}\text { Recover, } \\
\text { rate, (\%) }\end{array}$} \\
\hline & & $9 \mathrm{~h}$ & $24 \mathrm{~h}$ & $48 \mathrm{~h}$ & $72 \mathrm{~h}$ & & \\
\hline Negative control, unchallenged & 4 & $0 \%(0.5)$ & $0 \%(0)$ & $0 \%(0.4)$ & $0 \%(0)$ & $+1400 \pm 129^{a}$ & -— \\
\hline Positive control & 4 & $75 \%(2.5)$ & $75 \%(2.5)$ & $75 \%(2.0)$ & $75 \%(2.0)$ & $-162.5 \pm 25^{d}$ & $0 \%$ \\
\hline Non-encapsulated $\lg Y$ & 4 & $100 \%(2.0)$ & $75 \%(1.3)$ & $25 \%(1.0)$ & $0 \%(0)$ & $+937.5 \pm 111^{\mathrm{b}}$ & $100 \%$ \\
\hline Microencapsulated IgY & 4 & $75 \%(2.0)$ & $0 \%(0)$ & $0 \%(0)$ & $0 \%(0)$ & $+1325 \pm 119^{a}$ & $100 \%$ \\
\hline Aureomycin & 4 & $100 \%(2.0)$ & $50 \%(2.0)$ & $75 \%(1.5)$ & $50 \%(1.5)$ & $+650 \pm 71^{c}$ & $50 \%$ \\
\hline
\end{tabular}

Li et al. [83]

${ }^{1}$ All pigs except negative control were orally challenged with $5 \mathrm{~mL}$ of viable $E$. coli K88 organisms ( $10^{11} \mathrm{cfu} / \mathrm{mL}$ per pig) at time $0 \mathrm{~h}$. Challenged pigs were left untreated (positive control) or treated three times $(-1,4$ and $9 \mathrm{~h}$ after bacterial challenge) on the first day and twice a day for two consecutive days each time with $0.4 \mathrm{~g}$ non-encapsulated $\lg \mathrm{Y}, 2 \mathrm{~g}$ of microencapsulated $\lg \mathrm{Y}$ (equivalent to $0.4 \mathrm{~g}$ of $\lg \mathrm{Y}$ ) or $0.25 \mathrm{~g}$ of aureomycin. Diarrhea and weight gain were assessed for 3 days after challenge

${ }^{2} \mathrm{FC}$ score is the mean fecal consistency score: 0 , normal; 1 , soft feces; 2 , mild diarrhea; 3 , severe diarrhea. Pigs with a fecal score of $<1$ were considered not to have diarrhea

${ }^{3}$ Means in a column followed by same or no letter do not differ $(P>0.05)$ 
encapsulated IgY. In addition, weight gain over the three day period was significantly higher in pigs receiving encapsulated IgY compared with non-encapsulated IgY. Both encapsulated and non-encapsulated IgY treatments were numerically superior to an aureomycin treated group. However, this process will undoubtedly add additional costs. Additional study will be needed before microencapsulation can be applied under commercial conditions.

\section{The stability of IgY when subjected to feed processing}

Egg-yolk antibodies can be administrated to young pigs either as a preventive or prophylactic treatment or as a therapeutic treatment after infection occurs. It appears that adding antibodies to swine feeds in the form of whole egg powder or whole yolk powder may be the most practical method of inclusion of IgY for preventive or prophylactic treatment. It is not known if IgY antibodies can tolerate heat-based feed processing techniques such as pelleting. Presumably the stability of IgY antibodies would be similar to that for enzymes and that stability would be greatly influenced by temperature, duration of heat treatment and cooling period as well as the moisture content of the diet. It is well known that a change in moisture content from 95 to 90 or $85 \%$ dry matter can dramatically decrease the stability of proteins when heated to high temperatures. Preliminary studies by Marquardt et al. [84] have demonstrated that low temperature steam pelleting $\left(70{ }^{\circ} \mathrm{C}\right)$ did not reduce antibody titer. Further studies need to be carried out on this problem

\section{Specificity of $\lg Y$}

IgY is an attractive and effective alternative approach to antibiotics due to its high specificity. It should be noted that swine are exposed to many infectious agents in commercial operations and therefore the swine industry will benefit more from IgY antibodies if they are produced against a mixture of common disease causing organisms rather than one specific disease. If this approach works well, it may help to justify, to some extent, commercial application of these antibodies.

\section{Amount of product added to the diet or administrated by gavage}

The efficacy of IgY in the gastrointestinal tract is related to two factors namely the dose of antibodies and the concentration of pathogen. The results of Yokoyama et al. [79] demonstrated that antibodies pass through the digestive system within a relatively short period of time (slightly more than $24 \mathrm{~h}$ ). In addition, they can reach all sections of the gastrointestinal tract in less than $10 \mathrm{~h}$. The supply of antibodies in the intestine must be sufficiently high to prevent binding of pathogen to the intestinal receptors. The antibody must also be continuously or nearly continuously available in the intestine. Studies by Marquardt et al. [34] showed that $1.5 \mathrm{~g}$ per day per piglet was sufficient to prevent diarrhea induced by infection with $10^{10}$ ETEC and the addition of $0.2 \%$ of egg-yolk antibody in the diet was preventive against diarrhea in commercial farms. However, a considerable amount of additional research must be carried out to identify the best antigens to use and the appropriate prevention or treatment protocols for control of intestinal pathogens such as different strains of $E$. coli.

\section{The production cost of high quality lgY antibodies}

At present, the production cost of high quality IgY antibodies is higher than the cost of routine antibiotic inclusion [84]. Therefore, the development of methods for large-scale production of IgY which produce a high recovery and purity of IgY are needed. The method should be simple, economical and require few chemicals. In addition, there is no consensus on the most suitable IgY extraction method for commercial application [20] and this requires further study.

\section{Conclusions}

Oral administration of specific IgY appears to have considerable potential as a means of controlling diarrhea diseases and exerting growth-promoting activity in swine. IgY technology will probably provide the best alternative to antibiotics. Some advantages of IgY in the control of swine diseases are:

1) They are highly effective.

2) They are highly cost-effective with only a small amount of antibody required per pig.

3) Collection of eggs is non-invasive.

4) The treatment is safe and live organisms are not used.

5) The procedure is environmentally friendly.

6) No toxic residues are produced and there is no development of resistance.

7) The treatment can be used to control many different types of pathogens.

\section{Competing interests}

The authors declare that they have no competing interests.

\section{Authors' contributions}

$X L$ and $Y X$ carried out the literature review and drafted the manuscript. LW, YZ, SL participated in literature review. All authors read and approved the final manuscript.

\section{Acknowledgments}

The work from our laboratory that is reviewed in this manuscript was supported by funds from the National Natural Science Foundation of China (31001053; 30371053; 30871806). 


\section{Author details}

'School of Life Science and Technology, Dalian University of Technology, Dalian 116024, China. ${ }^{2}$ Ministry of Education Center for Food Safety of Animal Origin, Dalian 116620, China. ${ }^{3}$ Department of Pharmacy, Dalian Medical University, Dalian 116044, China. ${ }^{4}$ Dalian SEM Bio-Engineering Technology Co. Ltd, Dalian 116620, China.

\section{Received: 9 June 2015 Accepted: 30 July 2015}

Published online: 25 August 2015

\section{References}

1. Cromwell GL. Why and how antibiotics are used in swine production. Anim Biotechnol. 2002:13:7-27.

2. Khachatourians GG. Agricultural use of antibiotics and the evolution and transfer of antibiotic-resistant bacteria. Can Med Assoc J. 1998;159:1129-36.

3. Casewell M, Friis C, Marco E, McMullin P, Phillips I. The European ban on growth promoting antibiotics and emerging consequences for human and animal health. J Antimicrob Chemother. 2003;52:159-61.

4. U.S. Food and Administration. Phasing out certain antibiotic use in farm animals. [http://www.fda.gov/ForConsumers/ConsumerUpdates/ ucm378100.htm?source=govdelivery\&utm_medium=email\&utm_ source $=$ govdelivery]

5. Adeola O, Cowieson AJ. Opportunities and challenges in using exogenous enzymes to improve nonruminant animal production. J Anim Sci. 2011:89:3189-218.

6. Mroz Z. Organic acids as potential alternatives to antibiotic growth promoters for pigs. Adv Pork Prod. 2005;16:169-82.

7. Jacela JY, DeRouchey JM, Tokach MD, Goodband RD, Nelssen JL, Renter DG, et al. Feed additives for swine: Fact sheets-prebiotics and probiotics, and phytogenics. J Swine Health Prod. 2010;18:132-6.

8. Cho JH, Zhao PY, Kim IH. Probiotics as a dietary additive for pigs: Aa review. J Anim Vet Adv. 2011;10:2127-34.

9. Halas V, Nochta I. Mannan oligosaccharides in nursery pig nutrition and their potential mode of action. Animals. 2012;2:261-74.

10. Windisch WM, Schedle K, Plitzner C, Kroismayr A. Use of phytogenic products as feed additives for swine and poultry. J Anim Sci. 2008;86:140-8.

11. Gong J, Yin F, Hou Y, Yin Y. Review: Chinese herbs as alternatives to antibiotics in feed for swine and poultry production: Potential and challenges in application. Can J Anim Sci. 2014;94:223-41.

12. Jacela JY, DeRouchey JM, Tokach MD, Goodband RD, Nelssen JL, Renter DG, et al. Feed additives for swine: Fact sheets-High dietary levels of copper and zinc for young pigs, and phytase. J Swine Health Prod. 2010;18:87-91.

13. Pettigrew JE. Reduced use of antibiotic growth promoters in diets fed to weanling pigs: Dietary tools, Part 1. Anim Biotechnol. 2006;17:207-15.

14. Xu YP, Li XY, Jin LJ, Zhen YH, Lu YN, Li SY, et al. Application of chicken egg yolk immunoglobulins in the control of terrestrial and aquatic animal diseases: A review. Biotechnol Adv. 2011;29:860-8.

15. Carlander D, Kollberg H, Wejaker PE, Larsson A. Peroral immunotherapy with yolk antibodies for the prevention and treatment of enteric infections. Immunol Res. 2000;21:1-6.

16. Diraviyam T, Zhao B, Wang Y, Schade R, Michael A, Zhang XY. Effect of chicken egg yolk antibodies ( $\lg Y$ ) against diarrhea in domesticated animals: A systematic review and meta-analysis. PloS One. 2014;9, e97716.

17. Klemperer F. Ueber natürliche Immunität und ihre Verwerthung für die Immunisirungstherapie. Archiv für Experimentelle Pathologie und Pharmakologie. 1893;31:356-82.

18. Schade R, Hlinak A. Egg yolk antibodies, state of the art and future prospects. ALTEX. 1996;13 Suppl 1:5-9.

19. Schade R, Staak C, Hendriksen C, Erhard MH, Hugel H, Koch G, et al. The production of avian (egg yolk) antibodies: IgY. The report and recommendations of ECVAM workshop 21. ATLA. 1997;24:925-34.

20. Schade R, Calzado EG, Sarmiento R, Chacana PA, Porankiewicz-Asplund J, Terzolo HR. Chicken egg yolk antibodies (IgY-technology): A review of progress in production and use in research and human and veterinary medicine. Altern Lab Anim. 2005;33:129-54.

21. Gassmann M, Thömmes $P$, Weiser $T$, Hübscher U. Efficient production of chicken egg antibodies against a conserved mammalian protein. FASEB J. 1990;4:2528-31.

22. Larsson A, Carlander D, Wilhelmasson M. Immune response in chicken with different amounts of antigen. Food Agricult Immunol. 1998;10:29-36.
23. Coleman MA. Oral administration of chicken yolk immunoglobulins to lower somatic cell count in the milk of lactating ruminants. Alexandria, VA: United States Patent and Trademark Office; 1996. US Patent 5,585,098.

24. Erhard MH, Schmidt P, Zinsmeister P, Hofmann A, Munster U, Kaspers B. Adjuvant effects of various lipopeptides and interferon-gamma on the humoral immune response of chickens. Poult Sci. 2000;79:1264-70.

25. Fryer J, Firca J, Leventhal J, Blondin B, Malcolm A, Ivancic D, et al. IgY antiporcine endothelial cell antibodies effectively block human antiporcine xenoantibody binding. Xenotransplantation. 1999;6:98-109.

26. Jin LZ, Samuel K, Baidoo K, Marquardt RR, Frohlich AA. In vitro inhibition of adhesion of enterotoxigenic Escherichia coli K88 to piglet intestinal mucus by egg yolk antibodies. FEMS Immunol Med Microbiol. 1998;21:313-21.

27. Yokoyama H, Peralta RC, Diaz R, Sendo S, Ikemori Y, Kodama Y. Passive protective effect of chicken egg yolk immunoglobulins against experimental enterotoxigenic Escherichia coli infection in neonatal piglets. Infect Immun. 1992;60:998-1007.

28. Alexander TJL. Neonatal diarrhea in pigs. In: Gyles CL, editor. Escherichia coli in Domestic Animals and Humans. Wallingford: CAB International; 1994. p. 151-70.

29. Hampson DJ. Postweaning Escherichia coli diarrhea in pigs. In: Gyles CL, editor. Escherichia coli in Domestic Animals and Humans. Wallingford: CAB International; 1994. p. 171-91.

30. Zhang W, Berberov EM, Freeling J, He D, Moxley RA, Francis DH. Significance of heat-stable and heat-labile enterotoxins in porcine colibacillosis in an additive model for pathogenicity studies. Infect Immun. 2006;74:3107-14

31. Rapacz J, Hasler-Rapacz J. Polymorphism and inheritance of swine small intestinal receptors mediating adhesion of three serological variants of Escherichia coli-producing K88 pilus antigen. Anim Genet. 1986;17:305-21.

32. Waters JR, Sellwood R. Aspects of genetic resistance to K88 E. coli in pigs. In: Proceedings of the 2 nd World Congress on Genetics Applied to Livestock Production. Madrid: International committee for World Congress on Genetics Applied to Livestock Production; 4-8 October 1982. p. 362.

33. Imberechts H, Deprez P, van Driessche E, Pohl P. Chicken egg-yolk antibodies against F18ab fimbriae of Escherichia coli inhibit shedding of F18 positive E. coli by experimentally infected pigs. Vet Microbiol. 1997;54:329-41.

34. Marquardt RR, Jin LZ, Kim JW, Fang L, Frohlich AA, Baidoo SK. Passive protective effect of egg-yolk antibodies against enterotoxigenic Escherichia coli K88+ infection in neonatal and early-weaned piglets. FEMS Immunol Med Microbiol. 1999;23:283-8.

35. Zuniga A, Yokiyama H, Albicker-Rippinger $P$, Eggenberger $E$, Bertschinger $\mathrm{HU}$. Reduced intestinal colonisation with F18-positive enterotoxigenic Escherichia coli in weaned pigs fed chicken egg antibody against the fimbriae. FEMS Immunol Med Microbiol. 1997;18:153-61.

36. Owusu-Asiedu A, Baidoot SK, Nyachoti CM, Marquardt RR. Response of early-weaned pigs to spray-dried porcine or animal plasma-based diets supplemented with egg-yolk antibodies against enterotoxigenic Escherichia coli. J Anim Sci. 2002;80:2895-903.

37. Owusu-Asiedu A, Nyachoti CM, Marquardt RR. Response of early-weaned pigs to an enterotoxigenic Esherichia coli (K88) challenge when fed diets containing spray-dried porcine plasma or pea protein isolate plus egg yolk antibody, zinc oxide, fumaric acid or antibiotic. J Anim Sci. 2003:81:1790-8.

38. Owusu-Asiedu A, Nyachoti CM, Baidoo SK, Marquardt RR, Yang X. Response of early-weaned pigs to an enterotoxigenic Esherichia coli (K88) challenge when fed diets containing spray-dried porcine plasma or pea protein isolate plus egg yolk antibody. J Anim Sci. 2003;81:1781-9.

39. Heo JM, Woyengo TA, Kahindi RK, Kiarie E, Maiti P, Nyachoti CM. Ileal amino acid digestibility in egg from hyperimmunized- hens fed to weaned pigs and piglet response to diets contain egg products. Anim Feed Sci Tech. 2015:204:52-61.

40. Berberov EM, Zhou Y, Francis DH, Scott MA, Kachman SD, Moxey RA. Relative importance of heat-labile enterotoxin in the causation of severe diarrheal disease in the gnotobiotic piglet model by a strain of enterotoxigenic Escherichia coli that produces multiple enterotoxins. Infect Immun. 2004;72:3914-24.

41. Allen KP, Randolph MM, Fleckenstein JM. Importance of heat-labile enterotoxin in colonization of the adult mouse small intestine by human enterotoxigenic Escherichia coli strains. Infect Immun. 2006;74:869-75.

42. Clements JD. Construction of a nontoxic fusion peptide for immunization against Escherichia coli strains that produce heat-labile and heat-stable enterotoxins. Infect Immun. 1990;58:1159-66. 
43. Dubreuil JD, Letellier A, Harel J. A recombinant Escherichia coli heat-stable enterotoxin b (STb) fusion protein eliciting neutralizing antibodies. FEMS Immunol Med Mic. 1996;13:317-23.

44. You JS, Xu YP, He ML, McAllister TA, Thacker PA, Li XY, et al. Protection of mice against enterotoxigenic $E$. coli by immunization with a polyvalent enterotoxin comprising a combination of LTB, STa, and STb. Appl Microbio Biotechnol. 2011;89:1885-93.

45. You JS, Xu YP, Li HQ, Wang LH, Wu FF, Xu FX, et al. Chicken egg yolk immunoglobulin (IgY) developed against fusion protein LTB-STa-STb neutralizes the toxicity of Escherichia coli heat-stable enterotoxins. J Appl Microbiol. 2014;117:320-8.

46. Mead PS, Slutsker L, Dietz V, McCaig LF, Bresee JS, Shapiro C. Food-related illness and death in the United States. Emerg Infect Dis. 1999:5:607-25.

47. U.S. Department of Agriculture, Economic Research Service: Foodborne illness cost calculator: Salmonella. [http://www.ers.usda.gov]

48. Besser TE, Goldoft M, Pritchett LC, Khakhria R, Hancock DD, Rice DH. Multiresistant Salmonella typhimurium DT104 infections of humans and domestic animals in the Pacific Northwest of the United States. Epidemiol Infect. 2000;124:193-200.

49. Centers for Disease Control and Prevention. Outbreaks of multidrug-resistant Salmonella Typhimurium associated with veterinary facilities - Idaho, Minnesota, and Washington. Morb Mortal Wkly Rep. 2001;50:701-4.

50. Hurd HS, McKean JD, Griffith RW, Wesley IV, Rostagno MH. Salmonella enterica infections in market swine with and without transport and holding. Appl Environ Microbiol. 2002;68:2376-81.

51. Oosterom J. Epidemiological studies and proposed preventive measures in the fight against human salmonellosis. Int J Food Microbiol. 1991;12:41-51.

52. Yokoyama H, Umeda K, Peralta RC, Hashi T, Icatlo FC, Kuroki M, et al. Oral passive immunization against experimental salmonellosis in mice using chicken egg-yolk antibodies specific for Salmonella enteritidis and S. typhimurium. Vaccine. 1998;16:388-93.

53. Mathew AG, Rattanatabtimtong S, Nyachoti CM, Fang L. Effects of in-feed egg yolk antibodies on Salmonella shedding, bacterial antibiotic resistance, and health of pigs. J Food Protect. 2009;72:267-73.

54. Letellier A, Messier S, Lessard L, Quessy S. Assessment of different treatments to reduce Salmonella in swine. In: Proceedings of the $3 \mathrm{rd}$ International Symposium on the Epidemiology and Control of Salmonella in Pork. Washington, DC: lowa State University; 5-7 August 1999. p. 321-325.

55. Wood RL, Pospischil A, Rose R. Distribution of persistent Salmonella typhimurium infection in internal organs of swine. Am J Vet Res. 1989;50:1015-21.

56. Fedorka-Cray PJ, Kelley LC, Stabel TJ, Gray JT, Laufer JA. Alternate routes of invasion may affect pathogenesis of Salmonella typhimurium in swine. Infect Immun. 1995:63:2658-64.

57. Jensen VB, Harty JT, Jones BD. Interactions of the invasive pathogens Salmonella typhimurium, Listeria monocytogenes, and Shigella flexneri with M cells and murine Peyer's patches. Infect Immun. 1998;66:3758-66.

58. Saif $\amalg$, Wesley RD. Transmissible gastroenteritis and porcine respiratory coronavirus. In: Disease of Swine. 8th ed. Ames: Iowa State University Press; 1999. p. 295-325.

59. Yan QG, Ou Y, Guo WZ, Feng T, Fan WQ, Lai WL, et al. Isolation of SC-1 strain of transmissible gastroenteritis virus of swine and characteristic analysis of gene7. Chin J Vet Sci. 2007;27:613-6 (in Chinese).

60. Yang LL, Guo FS, Sun SF, Wu B, Chen HC. Comparsion of antigenicity between expressed proteins of the fragment including $S$ gene whole antigenic sites and the deleted fragment in porcine respiratory coronavirus of transmissible gastroeritis virus. Chin J Virol. 2005;21:384-8 (in Chinese).

61. Zuo Y, Fan J, Fan H, Li T, Zhang X. Prophylactic and therapeutic effects of egg yolk immunoglobulin against porcine transmissible gastroenteritis virus in piglets. Front Agric China. 2009;3:104-8.

62. Cui HZ, Jiang HL, Zhang JL, Zhang H, Qin GX. Study and application of the hyperimmunized yolk antibodies against TGEV and PEDV in piglets. China Anim Husbandry Vet Med. 2012;39:173-5 (in Chinese).

63. Wood EN. An apparently new syndrome of porcine epidemic diarrhea. Vet Rec. 1977;100:243-4.

64. DeBouck $P$, Pensaert M. Experimental infection of pigs with a new porcine enteric coronavirus CV 777. Am J Vet Res. 1980:41:219-23.

65. Pigpers A, van Nieuwstadt AP, Terpstra C, Verheijden JHM. Porcine epidemic diarrhea in a herd of breeding and finishing pigs. Vet Rec. 1993;132:129-31.

66. Kweon CH, Kwon BJ, Woo SR, Kim JM, Woo GH, Son DH, et al. Immunoprophylactic effect of chicken egg yolk immunoglobulin (lg Y) against porcine epidemic diarrhea virus (PEDV) in piglets. J Vet Med Sci. 2000;62:961-4.
67. Song WP, Xu FZ, Wang JL, Yang B, Lai PA. Effect of IgY treatment on porcine epidemic diarrhea virus (PEDV) in piglets. Acta Agriculturae Boreali- Sinica. 2003;18:114-5

68. Santosham M, Chandran A, Fitzwater S, Fischer-Walker C, Baqui AH, Black R. Progress and barriers for the control of diarrhoeal disease. Lancet. 2010;376:63-7.

69. Kaminjolo JS, Adesiyun AA. Rotavirus infection in calves, piglets, lambs and goat kids in Trinidad. Br Vet J. 1994;150:293-9.

70. Kuroki M, Ohta Y, Ikemori Y, Peralta RC, Yokoyama H, Kodama Y. Passive protection against bovine rotavirus in calves by specific immunoglobulins from chicken egg yolk. Arch Virol. 1994;138:143-8.

71. Yolken RH, Leister F, Wee SB, Miskuff R, Vonderfecht S. Antibodies to rotavirus in chickens' eggs: A potential source of antiviral immunoglobulins suitable for human consumption. Pediatrics. 1988;81:291-5.

72. Ebina T. Prophylaxis of rotavirus gastroenteritis using immunoglobulin. Arch Virol Suppl. 1996;12:217-23.

73. Ozpinar H, Erhard MN, Aytug N, Ozpinar A, Baklaci C, Karamuptuoglu S, et al. Dose-dependent effects of specific egg-yolk antibodies on diarrhea of newborn calves. Prevent Vet Med. 1996;27:67-73.

74. Vega CG, Bok M, Vlasova AN, Chattha KS, Fernández FM, Wigdorovitz A, et al. IgY antibodies protect against human rotavirus induced diarrhea in the neonatal gnotobiotic piglet disease model. PloS One. 2012;7, e42788.

75. Hong JW, Kwon OS, Min BJ, Lee WB, Shon KS, Kim IH, et al. Evaluation effects of spray-dried egg protein containing specific egg yolk antibodies as a substitute for spray-dried plasma protein or antibiotics in weaned pigs. Asian-Aust J Anim Sci. 2004;17:1139-44.

76. Chernysheva LV, Friendship RM, Dewey CE, Gyles CL. The effect of dietary chicken egg-yolk antibodies on the clinical response in weaned pigs challenged with a K88+ Esherichia coli isolate. J Swine Health Prod. 2003;12:119-22.

77. Kovacs-Nolan J, Mine Y. Microencapsulation for the gastric passage and controlled intestinal release of immunoglobulin Y. J Immunol Methods. 2005:296:199-209.

78. Shimizu M, Fitzsimmons RC, Nakai S. Anti-E. coli immunoglobulin Y isolated from egg yolk of immunized chickens as a potential food ingredient. J Food Sci. 1988:53:1360-6.

79. Yokoyama H, Peralta RC, Sendo S, Ikemori Y, Kodama Y. Detection of passage and absorption of chicken egg yolk immunoglobulins in the gastrointestinal tract of pigs by use of enzyme-linked immunosorbent assay and fluorescent antibody testing. Am J Vet Res. 1993;54:867-72.

80. Chang HM, Lee YC, Chen CC, Tu YY. Microencapsulation protects immunoglobulin in yolk (lgY) specific against Helicobacter pylori urease. J Food Sci. 2002:67:15-20.

81. Cho YH, Lee JJ, Park IB, Huh CS, Baek YJ, Park J. Protective effect of microencapsulation consisting of multiple emulsification and heat gelation processes on immunoglobulin in yolk. J Food Sci. 2005;70:148-51.

82. Li XY, Jin LJ, McAllister TA, Stanford K, Xu JY, Lu YN, et al. Chitosan-alginate microcapsules for oral delivery of egg yolk immunoglobulin (lgY). J Agr Food Chem. 2007:55:2911-7.

83. Li XY, Jin LJ, Uzonna JE, Li SY, Liu JJ, Li HQ, et al. Chitosan- alginate microcapsules for oral delivery of egg yolk immunoglobulin (IgY): in vivo evaluation in a pig model of enteric colibacillosis. Vet Immunol Immunop. 2009:29:132-6.

84. Marquardt RR, Li S. Control of diarrhea in young pigs using therapeutic antibodies. In: Proceedings of Allen D. Leman Swine Conference. Minneapolis, MN: University of Minnesota. 15-18 September 2001. p. 227-239.

85. Hatta H, Kapoor MP, Juneja LR. Bioactive components in egg yolk. In: Mine Y, editor. Egg Bioscience and Biotechnology. New Jersey: John Wiley \& Sons Inc; 2008. p. 185-237.

86. Chu WH, Gao GF. Application of chicken egg yolk immunoglobulins against Enterotoxigenic Escherichia coli in piglets. Chin J Vet Sci. 2006;26:616-8 (in Chinese).

87. Yokoyama H, Hashi T, Umeda K, Icatlo Jr FC, Kuroki M, Ikemori Y, et al. Effect of oral egg antibody in experimental F18+ Escherichia coli infection in weaned pigs. J Vet Med Sci. 1997;59:917-21.

88. Yang BL, Zhang YF, Wu JM. Research of hyperimmunized yolk antibodies for prevention and treatment of piglet dysentery. Am Sci Vet Med. 2002;10: 37-8 (in Chinese).

89. Xu FZ, Wang JL, Yang B, Song WP, Lai PA, Qin ZR, et al. Preparation and application of chicken egg yolk immunoglobulins against enterotoxigenic Escherichia coli in piglets. Acta Agr Boreali-Sinica. 2002;17:108-12 (in Chinese). 